\title{
Ultrastructure of the wild rice Oryza grandiglumis (Gramineae) in Costa Rica
}

\author{
Ethel Sánchez ${ }^{1}$, Tania Quesada ${ }^{2}$ \& Ana M. Espinoza ${ }^{2,3}$ \\ 1 Centro de Investigación en Estructuras Microscópicas, Universidad de Costa Rica, San José, Costa Rica. E-mail: \\ ethels@cariari.ucr.ac.cr \\ 2 Centro de Investigación en Biología Celular y Molecular, Universidad de Costa Rica, San José, Costa Rica. \\ 3 Escuela de Agronomía, Facultad de Ciencias Agroalimentarias, Universidad de Costa Rica, San José, Costa Rica.
}

Received 21-III-2003. Corrected 16-VI-2004. Accepted 23-XI-2004.

\begin{abstract}
Oryza grandiglumis is a wild species of rice endemic to tropical America. This species was first found in 1998 in the wetlands of Caño Negro, located in the northern part of Costa Rica. Twenty five plants of O. grandiglumis were processed for scanning electron microscope. An ultrastructural description of the leaf blade, ligule, auricles, spikelet and caryopsis, with an emphasis on structures of taxonomic value. The leaf blade has a characteristic cuticular wax pattern, composed of dense rod-like structures, and is surrounded by papillae, zipper-like silica cells, abundant bulky prickle trichomes, and hooked trichomes. The blade's edge has three rows of hooked prickle trichomes of various sizes. The auricles wrapped the culm, with long attenuated trichomes at the edges; the base was surrounded by oblong cells. The ligule is a blunt membrane covered by short prickle trichomes. Spikelet morphology is characteristic of the Poaceae family, but the sterile lemmas were nearly as long as the fertile lemmas, and they have an unique crown-like structure of lignified spines between the rachilla and the fertile lemmas. Comparison with Brazilian specimens of $O$. grandiglumis revealed little differences in the ultrastructural characteristics. Rev. Biol. Trop. 54(2): 377-385. Epub 2006 Jun 01.
\end{abstract}

Key words: wild rice, Neotropical endemic, Oryza grandiglumis, Costa Rica, ultrastructure, morphology.

Oryza grandiglumis (Döell) Prod. is a tetraploid wild Oryza species with a CCDD genome type (Oka 1961, 1988, Kihara 1963 in Vaughan 1989, Akimoto 1998). It is endemic to the Neotropics (Morishima and Martins 1993) and belongs to the O. officinalis complex (Tateoka 1962a, 1962b, Vaughan 1989, 1994). This species is found in Argentina, Bolivia, Brazil, Colombia, Ecuador, French Guyana, Paraguay, Venezuela and Peru (Pohl 1978, 1980, Morishima 1994, Vaughan 1994, Akimoto 1998, Vaughan and Tomooka 1999), at altitudes between $0 \mathrm{~m}$ and $230 \mathrm{~m}$ above sea level (Vaughan 1994). In Costa Rica, $O$. grandiglumis was first analyzed in 2001 and is distributed in the wetlands of Caño Negro, along the muddy shores of Río Frío, in San Carlos, province of Alajuela (Zamora et al. 1998). It grows sympatrically with the native
Oryza species, O. glumaepatula (Sánchez and Espinoza 2005).

This species grows in areas subject to seasonal flooding, such as open fields, muddy river banks and wetlands where the water is clear. During the rainy season, plants are dispersed vegetatively by the river currents, aided by their culms which have developed aerenchyma that allow the plant to float along the river current. Seeds are produced at the end of the rainy season and germinate when the water levels are low (Akimoto 1998, Zamora et al. 1998, 2003).

O. grandiglumis in Costa Rica may reach up to $760 \mathrm{~cm}$ in length, the product of culm elongation due to changes in water level. The leaf blades are broad, between 3 and $5 \mathrm{~cm}$ wide, and the ligule is blunt and pubescent. Auricles embrace the culm and are completely 
white, unlike other Oryza species that present purple-colored auricles (Zamora et al. 2002).

Panicles are prominent and have many thin ramifications. The sterile lemmas may reach the same length as the fertile lemmas (palea and lemma), a trait that distiguishes $O$. grandiglumis from other Oryza species (Akimoto 1998). The spikelets are the largest among the wild Oryza species found in Costa Rica, measuring an average of $8.9 \mathrm{~mm} \pm$ S.D. Anthers are large and have a brilliant yellow coloring, visible even through the lemma and palea. The flowering period in Costa Rica occurs between March and July, and again from November to December (Zamora 2001).

The aim of this work is to carry out an ultrastructure description of the leaf blade, ligule, auricles, inflorescence and caryopsis of O. grandiglumis.

\section{MATERIALS AND METHODS}

Plant material. Plants and spikelets of O. grandiglumis, accession numbers 277, 280, 275 were collected from Caño Negro Biological Reserve, in San Carlos, Alajuela $\left(10^{\circ} 52^{\prime} 16.1^{\prime \prime} \mathrm{N} ; 4^{\circ} 47^{\prime} 48.9^{\prime \prime} \mathrm{W}\right)$. The spikelets of $O$. grandiglumis from Brazil were provided by $\mathrm{M}$. Akimoto and the International Rice Research Institute (IRRI) germplasm bank (Philippines), accession numbers 105155 , 105156 and 105157 . The latter were planted in the greenhouse for later ultrastructural analyses of the vegetative structures.

Sample preparation for scanning electron microscopy. Samples of the adaxial and abaxial surfaces of the leaf blade, auricles, ligule and spikelets were fixed in a $2.5 \%$ glutaraldehyde and 2\% paraformaldehyde solution in $0.1 \mathrm{M}$ sodium phosphate buffer, $\mathrm{pH} 7.4$ (Karnovsky 1965), and were then washed with the sodium phosphate buffer. The samples were post-fixed with $1 \%$ osmium tetraoxide in the sodium phosphate buffer, washed with distilled water and dehydrated in an ethanol gradient. Four washes with terbutilic alcohol were later performed and the samples were dried by sublimation (Sublimator Eiko ID-2). The material was mounted on aluminum bases and covered with $20 \mathrm{~nm}$ of platinum (Ionic Cover Eiko IB-5). The samples were observed by scanning electron microscopes (Hitachi S-570 and $\mathrm{S}-2360 \mathrm{~N})$, with an acceleration voltage of $15 \mathrm{Kv}$.

Pollen and spikelet analyses. Anthers were homogenized in a $10 \%$ sodium hydroxide solution, were washed with distilled water, centrifuged (Hitachi 05 PR-22 centrifuge) and cleaned using ultrasound (Astrason sonicator, $11 \mathrm{H})$. The material was fixed with $1 \%$ osmium tetraoxide in the $0.1 \mathrm{M}$ sodium phosphate buffer and samples were processed as described previously (Sánchez 1999). The spikelets were placed in an incubator for 48 hours at $37^{\circ} \mathrm{C}$ and were then mounted and observed through the scanning electron microscope.

\section{RESULTS}

In the Costa Rican and Brazilian accessions, adaxial and abaxial surfaces of the leaf blade presented the same ultrastructural patterns (Fig. 1): several rows of silica cells alternating with bulky prickle trichomes (Fig. 1a, 1c, 1f); oblong and bilobular papillae (Fig 1d, 1e, 1f); stomata of $c a .5 .4 \mu \mathrm{m}$ in length which are surrounded by waxy papillae (Fig. 1f); bilobular papillae that present a very abundant waxy pattern with alternating bulky erect trichomes ( $\mathrm{ca}$. $18 \mu \mathrm{m}$ in length); bilobular papillae and rows of stomata (Fig 1a). This pattern was repeated throughout the blade surface (Fig. 1a).

The edge of the leaf blade presented three types of prickle trichomes: an abundant type of elongated trichomes that measured $c a .243$ $\mu \mathrm{m}$ (Fig 1b); and two types of small bulky trichomes, organized in a heterogeneous pattern (Fig. 1b y 1c) towards the inner part of the surface. Of the latter two types, one type measured ca. $48 \mu \mathrm{m}$ and was surrounded by silica cells and the smaller, more abundant type was tilted, measuring $c a$. $17 \mu \mathrm{m}$ and was surrounded by bilobed papillae. 

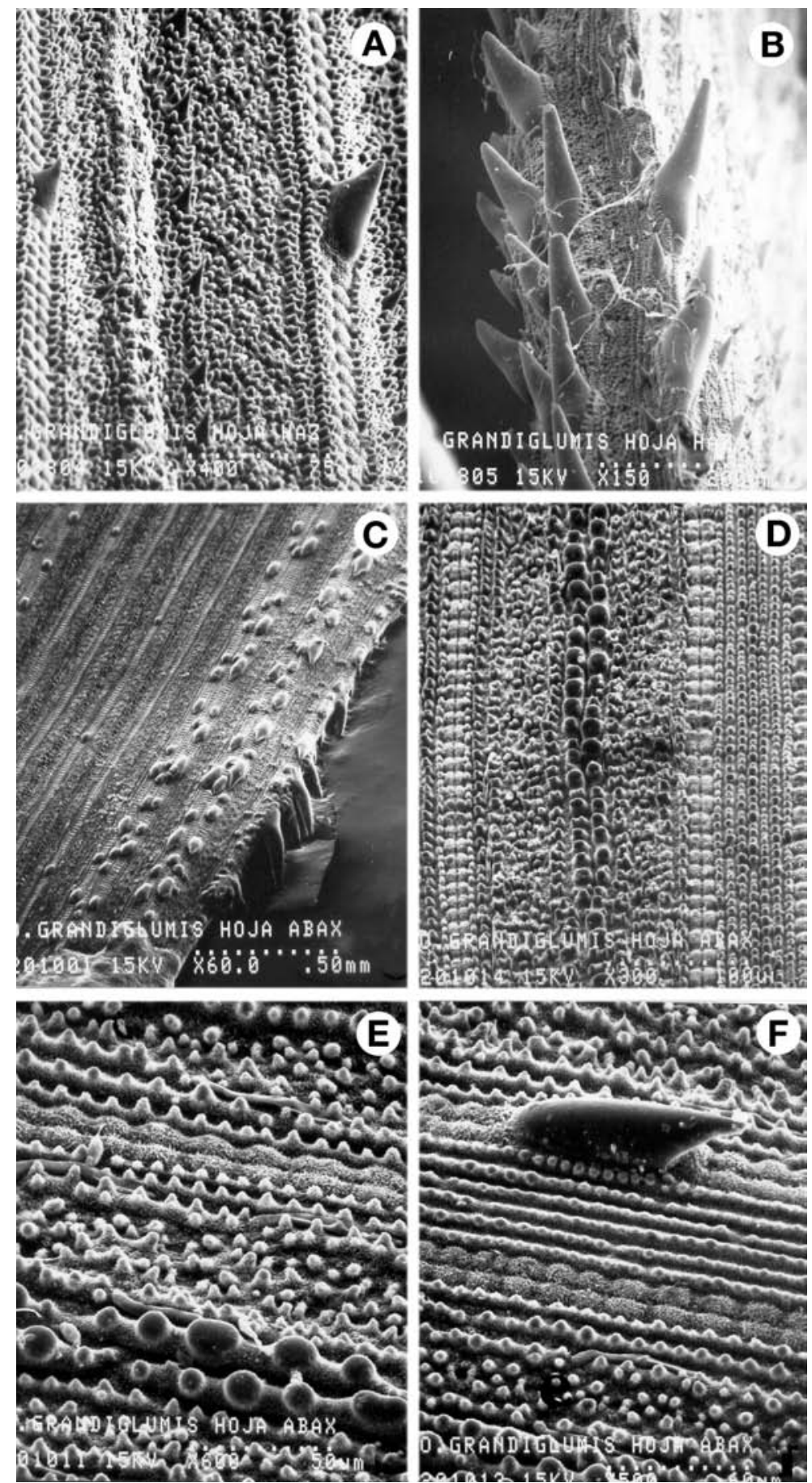

Fig. 1. Scanning electron micrographs of the leaf blade of Oryza grandiglumis from Costa Rica. A) Bulky prickle trichomes. Papilllae and small prickle trichomes on the adaxial surface of the leaf blade. (Bar. $75 \mu \mathrm{m}$ ). B) Trichomes on the edge of the leaf blade. (Bar. $200 \mu \mathrm{m}$ ). C) Abaxial surface of the leaf blade. (Bar. $0.50 \mu \mathrm{m}$ ). D) Papillae on the abaxial surface of the leaf blade. (Bar. $100 \mu \mathrm{m})$. E) Detail of the cuticular pattern of the abaxial surface of the leaf blade. (Bar. $50 \mu \mathrm{m})$. F) Distribution of waxy papillae and a bulky prickle trichome on the abaxial surface of the leaf blade. (Bar. $60 \mu \mathrm{m})$. 
The leaf blade was covered by cuticular wax, composed of diverse waxy rods, that formed a very dense layer on both adaxial and abaxial surfaces (Figs. 1a, e, f), a trait that was not observed in any other wild Oryza species in Costa Rica (Sánchez 1999).

The ligule and auricles could be observed by separating the leaf blade from the sheath. The auricles embraced the culm and measured ca. $5 \mathrm{~mm}$ (Fig. 2a). These surrounded the leaf blade and presented numerous spiny trichomes that measured $c a .35 \mu \mathrm{m}$ (Fig. 2a). The auricle edges showed large, attenuate trichomes of $c a$. $2 \mathrm{~mm}$ in length with oblong cells of different sizes covering its base (Fig. 2b).

The ligule was blunt in the distal end and measured $c a .3$ to $6 \mathrm{~mm}$. It was covered by prickle and attenuate trichomes that were more abundant in the distal end (Fig. 2c). Ligule and auricles of the Costa Rican and Brazilian specimens did not show significant morphological differences at the ultrastructural level.

The spikelet (Fig. 2d) is awned and the lemma and palea were covered by spiny trichomes and lignified papillae, and the apiculus presented abundant large prickle trichomes in the distal end of the palea (Fig. 2e). In addition, the rachilla that joins the fertile lemmas with the sterile lemmas was clearly observed (Fig. $2 \mathrm{~d}$ ), as well as a spiny crown-like structure, located between the rachilla and the fertile lemmas (Fig. 2f). The raquilla was covered by small, spiny trichomes (Fig. 2f), whereas the sterile lemmas were smooth, with a serrated edge (Fig. 2d) and stomata at the base (Fig. 3a). Furthermore, the fertile lemmas (lemma and palea) presented a cellular structure similar to a fine-woven mesh (Fig. 3b), and were composed of rows of lignified structures, with one or two spine-like projections (Fig. 3c). Prickle trichomes were also observed between these rigid structures, due to the presence of lignin and silica (Figs. 3b, c). The spikelet presented six bassifix anthers that measure $c a$. 4 to $5 \mathrm{~mm}$, each one formed by four lobes and its filament (Fig. 3d). The ovary (Fig. 3e) was composed of two feathery stigmata, constituted by an array of short cells of different shapes (Figs. 3e, f).
Pollen grains are characteristic of the genus Oryza. These were monopore and measured ca. $36 \mu \mathrm{m}$ in diameter, with a very simple exin ornamentation (Figs. 4a, b).

Figure $4 \mathrm{c}$ shows the caryopsis of the species $O$. grandiglumis from Brazil, and figure $4 \mathrm{~d}$ shows the caryopsis of $O$. grandiglumis from Costa Rica. Macroscopically, it seemed that the sterile lemmas did not have the same morphology, however, when the ultrastructure was analyzed, it was observed that both species have a very similar anatomy. Brazilian sterile lemmas are of equal length as the fertile lemmas as well as having a very similar external morphology. Costa Rican sterile lemmas are asymmetric and rarely cover over $50 \%$ of the fertile lemmas. These appeared smooth on the surface, but when higher magnification was used, the structural pattern was similar to the Brazilian sterile lemmas.

\section{DISCUSSION}

O. grandiglumis presented an epidermal pattern very similar to that of other Oryza species, as was confirmed by previous works done by Sony Parry (1973), Hoagland and Paul (1978), Terrel and collaborators (2001) and Sánchez et al. (2003). Although the morphology of the cuticular wax pattern was similar to that of other Oryza species (Juniper and Bradley 1958, Eglinton and Hamilton 1967), O. grandiglumis presented a higher wax density (Stant 1993, Sánchez 1999), compared to other Oryza species (DeBary 1972 in Hoagland and Paul 1978). In addition, structures observed on the edge of the leaf blade were unique for this species; therefore, these could be useful for diagnostic purposes (Sánchez 1999).

$O$. grandiglumis presented similarities to some structures of $O$. latifolia, such as the ligule and auricles, traits that they do not share with other Oryza species found in Costa Rica (Sánchez et al. 2003). This was highly expected since $O$. grandiglumis and $O$. latifolia are tetraploid species that share the CCDD genome (Kihara 1963 in Vaughan 1994). Therefore, the 

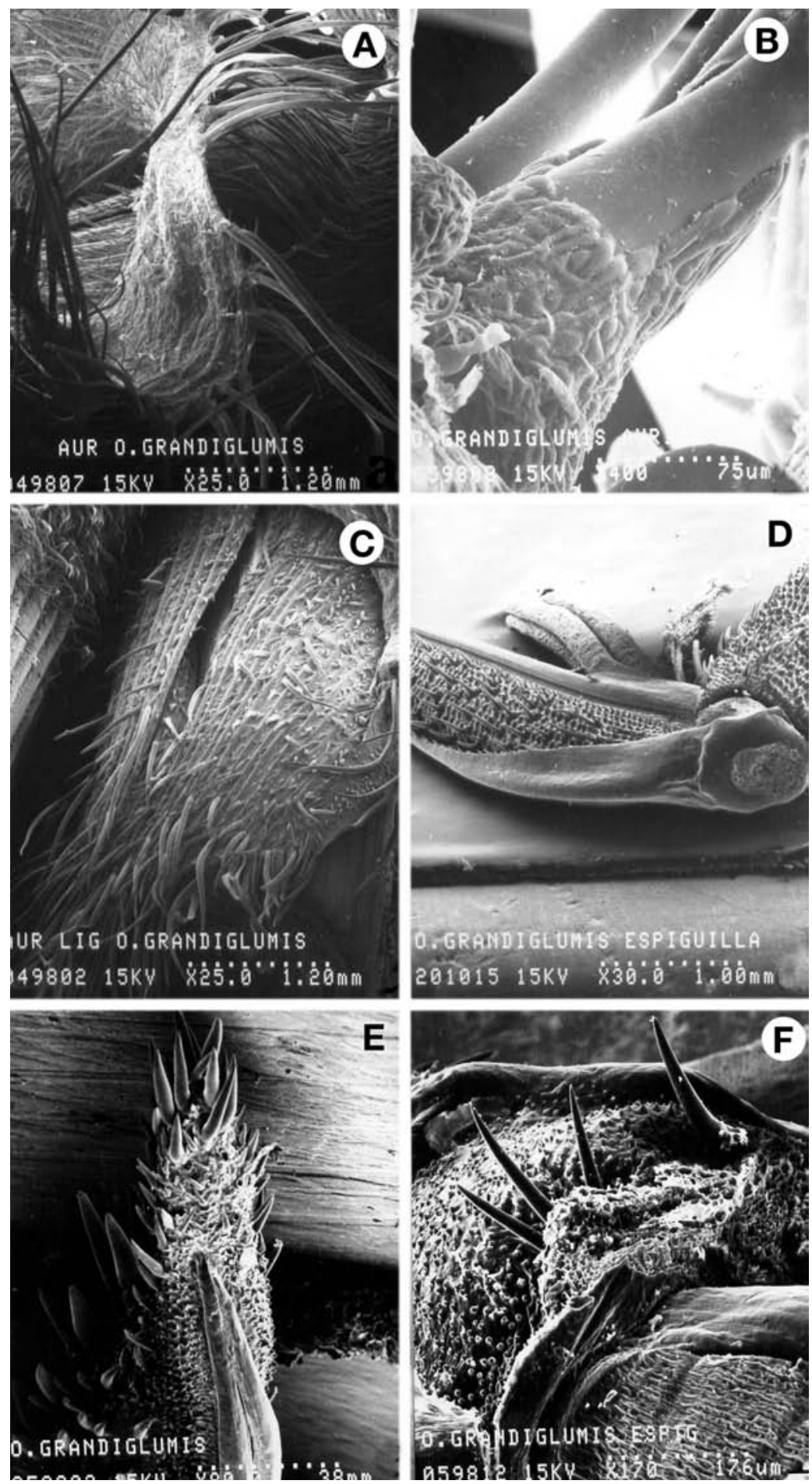

Fig. 2. Scanning electron micrographs of the ligule, auricles and spikelets of Costa Rican accessions Oryza grandiglumis. A) Auricles. (Bar. $1.20 \mathrm{~mm}$ ). B) Base of the attenuate trichomes of the auricles. (Bar. $75 \mu \mathrm{m}$ ). C) Ligule. (Bar. 1.20 mm). D) Spikelet. (Bar. $1.0 \mathrm{~mm}$ ). E) Spikelet apiculus. (Bar. $0.38 \mathrm{~mm})$. F) Spiny crown-like structure of the raquilla. (Bar. $176 \mu \mathrm{m})$. 

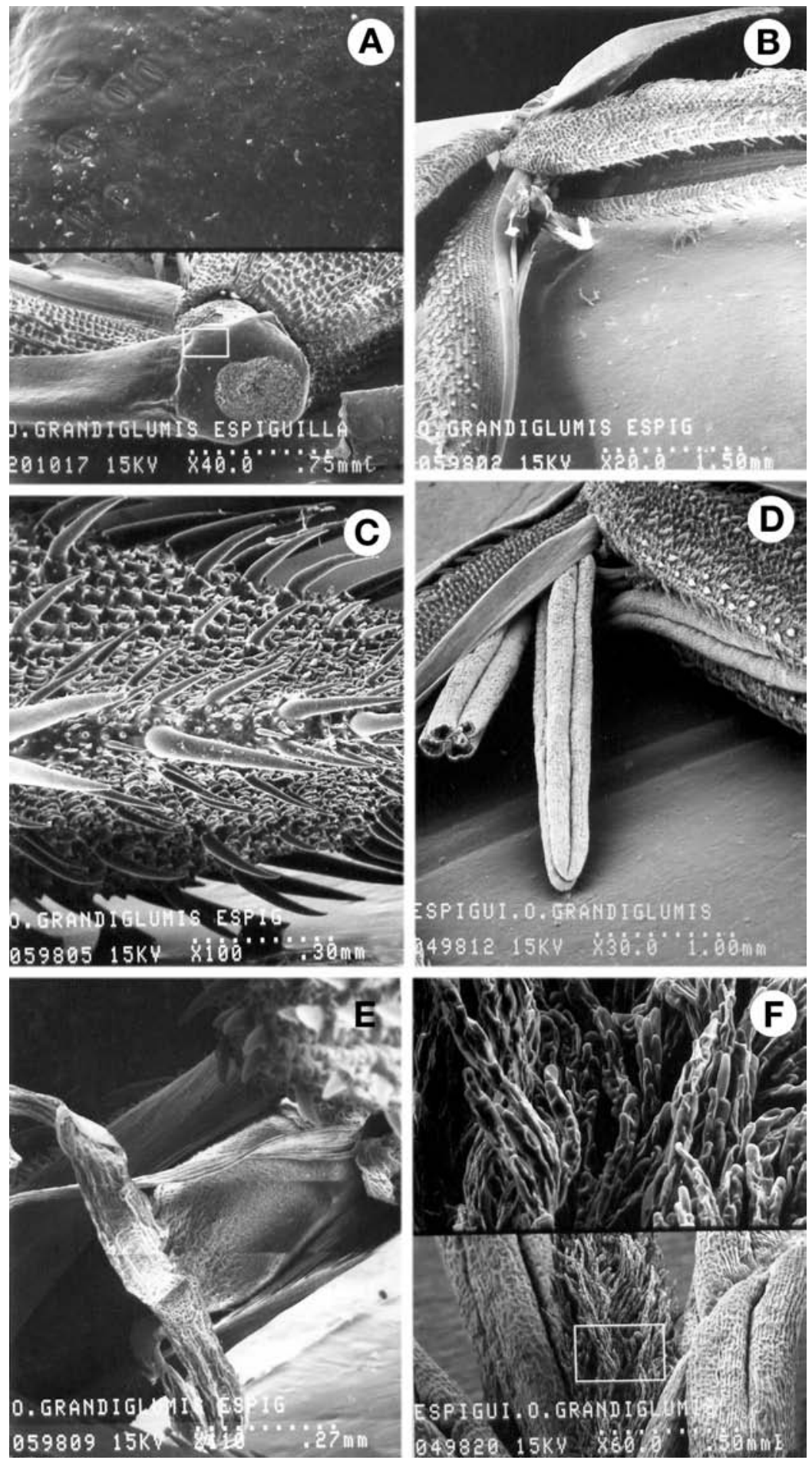

Fig. 3. Scanning electron micrograph of the spikelet of Costa Rican accessions of Oryza grandiglumis. A) Stomata on the base of the sterile lemmas. (Bar. $0.75 \mathrm{~mm}$ ). B) Fertile lemmas. (Bar. $1.50 \mathrm{~mm}$ ). C) Spikelet surface. (Bar. $0.30 \mathrm{~mm}$ ). D) Anthers. (Bar. $1.00 \mathrm{~mm}$ ). E) Ovary. (Bar. $0.27 \mathrm{~mm})$. F) Elongated cells that compose the feathery stigmata. (Bar. $0.50 \mathrm{~mm}$ ). 

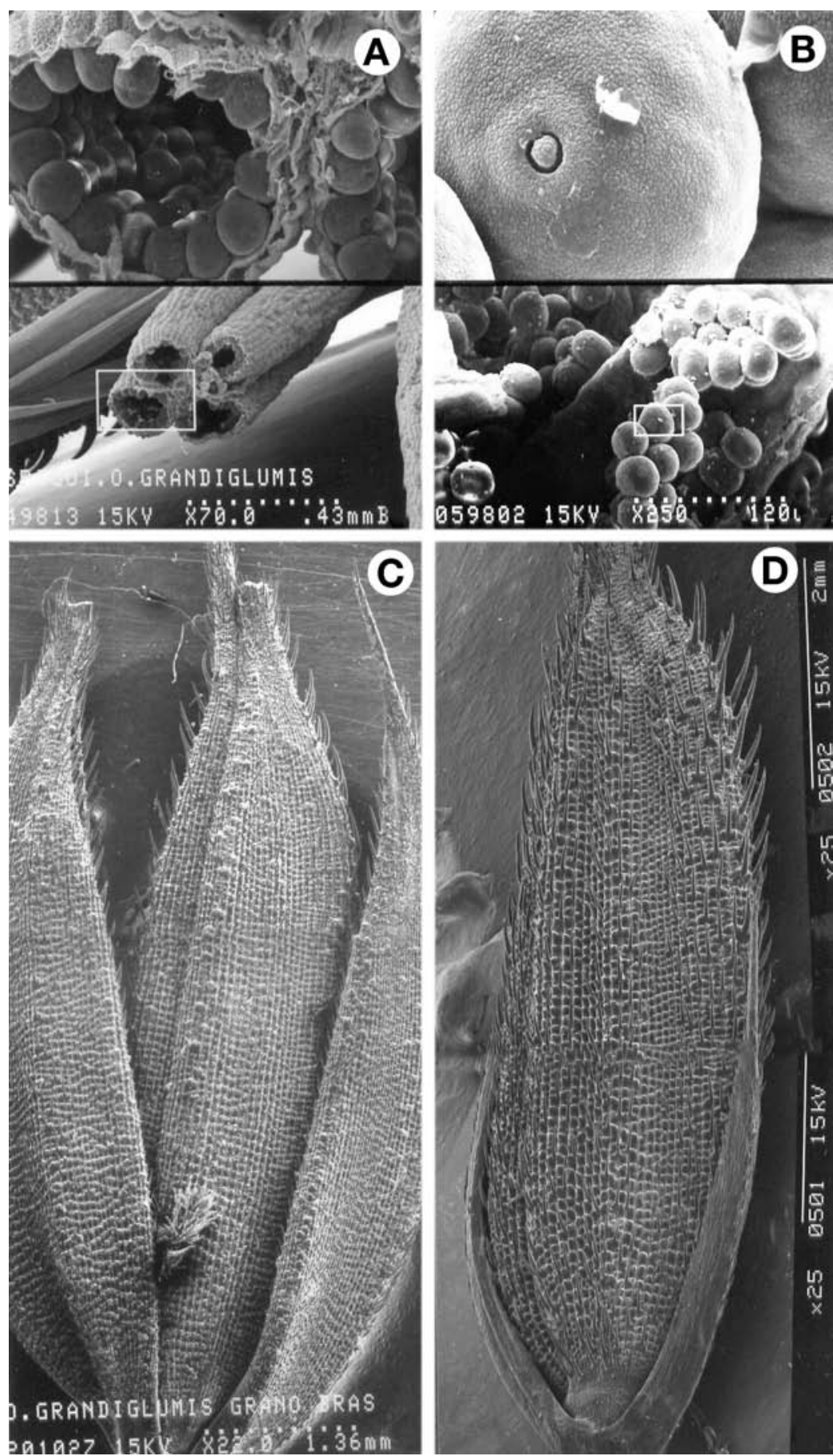

Fig. 4. Scanning electron micrographs of the anthers, pollen grains and karyopsis of Oryza grandiglumis from Costa Rica and Brazil. A) Distribution of pollen grains in the anther. (Bar. $0.43 \mathrm{~mm}$ ). B) Detail of the external morphology of the pollen grain (Monopore pollen grain). (Bar. $120 \mu \mathrm{m}$ ). C) Spikelet of the Brazilian O. grandiglumis. (Bar. $1.36 \mathrm{~mm}$ ). D) Spikelet of the Costa Rican O. grandiglumis. (Bar. $2 \mathrm{~mm}$ ). 
genotypical closeness is reflected at the phenotypical level. O. grandiglumis is the only Oryza species that presents large sterile lemmas that partially cover the fertile lemmas. In addition, the unique spiny crown-like structure observed between the fertile lemmas, is an important taxonomic characteristic since it was absent in other Costa Rican Oryza species.

The comparison of the Brazilian and Costa Rican spikelet morphology revealed that the sterile lemmas of the former are larger and more robust, and that the epidermis presents a more prominent cuticular pattern than that of the Costa Rican species. The large sterile lemmas of the Brazilian O. grandiglumis are believed to facilitate the floating capacity of the seed, an adaptation that is absent the Costa Rican species (Zamora 2001). Nevertheless, in observing other anatomical structures by scanning electron microscope, both Brazilian and Costa Rican species were morphologically similar.

Although the inhabitants of the area where this species is found have occasionally used O. glumaepatula as an alternative food source for several years, the recent report of this species in Costa Rica and Central America offers the possibility of increasing the rice gene pool as a source of useful genes that could be potentially incorporated in rice improvement and could represent a new source of income, as a "gourmet rice", for the inhabitants of the area where this species is found.

This study was part of a comprehensive research project on the characterization of wild Oryza species in Costa Rica. Complementing this ultrastructural study, the morphological, genetic, and life history studies were also performed (Zamora 2001). The ultrastructural comparison between the Brazilian and Costa Rican accessions of $O$. grandiglumis suggested that both are the same species, results that were later confirmed by genetic studies using molecular markers (Zamora 2001). Although O. grandiglumis is partly protected, we hope that this information could contribute to help increase the knowledge of this species, and to highlight its importance among the local community.

\section{ACKNOWLEDGMENTS}

The authors thank Enrique Freer and Francisco Hernández for their valuable collaboration.

\section{RESUMEN}

El arroz silvestre Oryza grandiglumis es endémico de América. Se localiza en la zona norte de Costa Rica, principalmente en el humedal de Caño Negro y del Río Medio Queso. Es una planta vigorosa y grande. Su nombre deriva del gran tamaño de las lemas estériles (glumas). Presentamos una descripción ultraestructural de la lámina foliar, lígula, aurículas, espiguilla y cariópside, con énfasis en las estructuras de valor taxonómico, usando el microscopio electrónico de barrido. La lámina foliar se caracteriza por presentar un patrón de cera cuticular en forma de densos bastoncillos. Presenta estomas rodeados de papilas, células de sílice en forma crenada, varias formas de papilas de cera, distribuidas en forma muy regular, y tricomas espinosos abultados en la base y tricomas ganchudos. En el borde de la lámina hay tres hileras de tricomas espinosos ganchudos de diferente tamaño. Las aurículas son envolventes y los bordes presentan tricomas atenuados largos cubiertos en la base por células alargadas. La lígula es truncada y cubierta de tricomas espinosos pequeños. La morfología de la espiguilla es algo similar a las de las otras especies de la familia Poaceae, pero las lemas estériles son casi del mismo tamaño que las fértiles. Además se observó entre la raquilla y las lemas fértiles una corona de espinas lignificadas. Ultraestructuralmente, esta población es similar a las brasileñas.

Palabras clave: arroz silvestre, endémico, neotropical, Oryza grandiglumis, Costa Rica, ultraestructura, morfología.

\section{REFERENCES}

Akimoto, M. 1998. Population genetic structure of the wild rice Oryza glumaepatula Steud. distributed in the Amazon flood area influenced by-history traits. Molec. Ecol. 7: 1371-1381.

Eglinton, G. \& R. Hamilton. 1967. Leaf cuticular waxes. Science 156: 1322-1335. 
Hoagland, R.E. \& R.N. Paul. 1978. A Comparative SEM study of red rice and several commercial rice (Oryza sativa) varieties. Weed Sci. 26: 619-625.

Juniper, B.E. \& D.E. Bradley. 1958. The carbon replica technique in the study of the ultrastructure of leaf surfaces. J. Ultrastruct. Res. 21: 16-27.

Karnovsky, M.J. 1965. A formaldehyde-glutaraldehyde fixative of high osmolarity for use in electron microscopy. J. Cell Biol. 27: 137.

Morishima, H. 1994. Background information about Oryza species in tropical America. In Investigations of plant genetic resources in the American basin with emphasis on the genus Oryza: Report of 1992/ 93 Amazon Project; Monbusho Int. Sci. Res. Prog. 102 p.

Morishima, H. \& P. Martins. 1993. Investigations of plant genetic resources in the Amazon Basin with the emphasis on the genus Oryza. Report of 1992/93 Amazon Project. The Mombusho Int. Sci. Res. Prog. Japan Research Support Foundation of the State of Sao Paulo, Brazil. 96 p.

Oka, H. 1961. Report of trip for investigation of rice in Latin America. (mimeo; without data). 158 p.

Oka, H. 1988. Origin of cultivated rice. Blavier/ Sci. Soc. Amsterdam. Tokyo. 179 p.

Pohl, W.R. 1978. How to know the grasses. Wm. C. Brown. Bubuque, Iowa, USA.

Pohl, W.R. 1980. Flora costaricensis, Family $\mathrm{N}^{\mathrm{o}}$ 15, Gramineae. W. Burger, Fieldiana Botany. 680 p.

Sánchez, E. 1999. Comparación morfológica ultraestructural de las especies silvestres de arroz Oryza: Poaceae en Costa Rica. Tesis de Licenciatura en Biología. Escuela de Biología, Universidad de Costa Rica, San José, Costa Rica. 114 p.

Sánchez, E. \& A.M. Espinoza. 2005. Description of the ultrastructure of Oryza glumaepatula, a wild rice species endemic of tropical America. Rev. Biol. Trop. 53: $15-22$.

Stant, M.Y. 1973. Scanning electron microscopic silica bodies and other epidermal features in basis (Tradescantia) leaf. Bot. J. Linn. Soc. 233-244.

Tateoka, T. 1962a. Taxonomic studies of Oryza I, O. latifolia complex. Bot. Mag. Tokyo 75: 418-427.

Tateoka, T. 1962b. Taxonomic studies of Oryza II. Several species Complex. Bot. Mag. Tokyo 75: 455-461.

Terrel, E.E., P.M. Peterson \& W.P. Wergin. 2001. Epidermal Features and Spiketel Micromorphology in Oryza and Related Genera (Poaceae: Oryzeae). Smith. Contr. Bot. 91: 50 p.

Vaughan, D.A. 1989. The genus Oryza L. Current status of taxonomy. IRPS. 138: 1-21. IRRI, Manila, Philippines.

Vaughan, D.A. 1994. The wild relatives of rice, a genetic resources handbook. International Rice Research Institute (IRRI). Manila, Philippines. 130 p.

Vaughan, D.A. \& N. Tomooka. 1999. Wild rice in Venezuela. Rice Genetic Newsletter. 16: 15-17.

Zamora, A., E. Sánchez, T. Quesada \& A.M. Espinoza 1997. Especies silvestres, reserva de genes para el mejoramiento de arroz. RedBio’ 98. p 57.

Zamora, A., E. Sánchez, T. Quesada, C. Muñoz, P. Porras, C. Quesada \& A.M. Espinoza 1998. Wild species, reservoirs of useful genes for the genetic improvement of rice. In International Symposium on Rice Germplasm Evaluation and enhacement. Stuttgart, Arkansas, U.S.A.

Zamora, A., C. Barboza, J. Lobo \& A. M. Espinoza. 2003. Diversity of native rice (Oryza: Poaceae) species of Costa Rica. Gen. Res. Crop Evol. 50: 855-870.

Zamora, A. 2001. Diversidad morfológica y genética del género Oryza (Poaceae) en Costa Rica. M.Sc. Thesis. University of Costa Rica, San José, Costa Rica. 
